\title{
LEMBRANÇAS, LUIZ CARLOS NOGUEIRA
}

\author{
Maria Aparecida de Luna Pedrosa \\ Universidade Federal do Paraná
}

Oostumo dizer que a saudade é a testemunha da boa convivência, e esta
merece ser relembrada e recontada.
Conheci Luiz Carlos nos anos oitenta, mais precisamente em 1984. Eu
concluía disciplinas de meu Mestrado, no Instituto de Psicologia da Univer-
sidade de São Paulo. Nestes anos, podia-se notar que começava um movi-
mento de abertura à Psicanálise, o reconhecimento da pesquisa em
Psicanálise e o trabalho sobre os textos de Lacan, muitos ainda não traduzi-
dos. Não se tratava de pensar a pesquisa sob o viés de uma psicologia psico-
dinâmica de inspiração norte americana, ou de uma psicologia sob a ótica da
escola inglesa. Via-se a chegada de inspiração freudiana e lacaniana nos
redutos acadêmicos mais respeitados no Brasil, e Luiz Carlos Nogueira lá
estava presente, nestes tempos, com seu modo atencioso, polido e reservado.
Conversamos, pela primeira vez, para avaliar a minha inclusão como aluna,
em uma disciplina sua, na pós-graduação. Assisti a Luiz Carlos, ocupando
seu lugar como professor, mas sem arredar de seu lugar como psicanalista -
"nós, ou os psicanalistas como nós, os que pensam e vivem na sua prática a
Psicanálise", dizia (apenas uma lembrança desse 1984, em suas aulas, isto é,
ainda vivo para mim, porque eu reparava e admirava essa postura). Jamais
se furtou em se apresentar como psicanalista e pesquisador da Psicanálise no
mundo universitário. Luiz Carlos foi um dos acadêmicos que contribuiu,
desde esse tempo, para a investigação séria e responsável em Psicanálise, o
que era bastante ousado, porque se fazia uma mudança sobre os modelos de
pesquisa até então praticados no campo da Psicologia. E bem sabemos as
razões, uma vez que os modelos eram todos exigentes de provas, às quais 
não bastavam os testemunhos da palavra, e só atendendo essas exigências é que se podia obter o reconhecimento como pesquisador. E, ainda se ouvia naquela época que, com Psicanálise, não era possível fazer ciência.

Mas foi com Luiz Carlos que li, com o devido cuidado e comentários também muito precisos, o Seminário 11, e descobri nos seus modos e estilo, modesto até, o caminho sobre como ensinar sobre temas da Psicanálise. Os recortes sobre cada capítulo eram precisos e claros, quando não acompanhados de exemplos da prática e do praticante da Psicanálise.

A afinidade com o professor e analista pouco a pouco se firmou, víamos-nos em alguns dos Encontros Nacionais da Psicanálise e em Jornadas de Cartéis, às quais, por exemplo, Luiz Carlos, acompanhado por Helena, comparecia em Curitiba, na então Associação Causa Freudiana. Luiz Carlos foi um estimado companheiro de trabalho de colegas curitibanos.

A admiração e respeito pelo Psicanalista e investigador se manteve, de modo que pude propor uma primeira aventura sobre a Psicanálise, no âmbito universitário em Curitiba, nos anos noventa, de 1994 a 1996. Ocorreu que, juntamente com outra colega do Curso de Psicologia, desenvolvi o primeiro projeto de especialização em Psicanálise e Psicologia. A empreitada, na $\mathrm{Cu}-$ ritiba tão conservadora, não ocorreu sem críticas na comunidade. Luiz Carlos esteve sempre disponível a ouvir, falar e, cautelosamente, aconselhar como um experiente nesse ensino; suas observações ou comentários nos estimulou a dar andamento ao projeto.

Luiz Carlos, sem saber, contribuiu para a fundação do ensino e transmissão sobre a Psicanálise, no âmbito acadêmico da Universidade Federal do Paraná, no Departamento de Psicologia, no qual eu lecionava. Outros colegas, naturalmente, deram sua contribuição, mas pela peculiaridade de trabalho de ensino no espaço universitário, foi, de fato, seu, o exemplo. Assim, por alguns anos ainda, Luiz Carlos manteve-se ligado à Universidade Federal do Paraná, também com o Departamento de Filosofia, no qual teve participação na criação do primeiro Grupo de Pesquisa institucional voltado à Psicanálise, sob sua orientação e coordenação de Maria Cristina Sparano. Ele inspirou, também, esta colega, na organização de um curso de especiali- 
zação em Psicanálise e Linguagem, no Departamento de Filosofia, na mesma universidade. A Psicanálise, enfim, encontrava lugar nessa instituição tão séria, tradicional e conservadora.

Luiz Carlos mostrava-se contente cada vez que encontrava os colegas Psicanalistas e amigos em comum, e com Curitiba. Embora, algumas vezes, demonstrasse cansaço, não deixava que o mesmo fizesse obstáculo ao seu discreto entusiasmo com o ensino, que também foi além das portas da Universidade. Por meio de transferências de trabalho manteve-se como orientador e supervisor, de praticantes da Psicanálise que se reuniam em finais de semana; Maria Carolina e Daniel Serafim estavam à frente desses encontros. E lá estava nosso colega, incansável, debruçando-se junto aos seus ouvintes sobre os textos de Psicanálise, revendo Lacan, Freud, orientando a leitura de outros autores, dos mais diversos agrupamentos dentro da Psicanálise. Com isso, mostrava a importante e necessária abertura às produções e publicações, incentivando a pesquisa e a crítica, mantendo-se sempre cuidadoso com o contexto conceitual e a clínica analítica.

Luiz Carlos foi meu Mestre, meu colega, amigo e ouvinte, que, com seu silêncio e sua atenção, aconselhava. A discrição foi sempre sua marca.

Experimentei a perda de Luiz Carlos como muitos colegas, geograficamente e afetivamente mais próximos, experimentaram. Uma perda que surpreendeu e, que, ao deixar saudade, mostrou o quanto sua presença foi importante e valiosa. Luiz Carlos demonstrou que a vida só tem sentido se puder ser acompanhada do prazer do trabalho, parte do viver daquele que se sabe no que deseja.

Só resta, ainda que hoje sem sua presença, dizer que sou muitíssimo grata aos tempos de trabalho a seu lado, pela inspiração e ensinamentos de vida acadêmica e de psicanalista, que me impulsionaram a abrir espaços de ensino da Psicanálise no campo universitário, de modo a contribuir para a existência da mesma nesse âmbito, com a devida dignidade.

Posso ter a tristeza diminuída quando posso lembrar da presença boa que ficou em minha memória. 